\title{
Novel insights into the synergistic interaction of Bortezomib and TRAIL: tBid provides the link
}

\author{
Simone Fulda \\ ${ }^{1}$ Institute for Experimental Cancer Research in Pediatrics, Goethe-University Frankfurt, Komturstr. 3a, 60528 Frankfurt, \\ Germany \\ Correspondence to: Simone Fulda, email: simone.fulda@kgu.de \\ Keywords: cancer, apoptosis, chemotherapy, proteasome inhibitor, TRAIL
}

Received: April 19, 2011, Accepted:May 14, 2011, Published: May 16, 2011

Copyright: @ Fulda. This is an open-access article distributed under the terms of the Creative Commons Attribution License, which permits unrestricted use, distribution, and reproduction in any medium, provided the original author and source are credited.

ABSTRACT:

\begin{abstract}
The proteasome inhibitor Bortezomib has been identified as a potent enhancer of TRAIL-induced apoptosis in several human cancers. However, the identification of the underlying molecular mechanisms of this synergistic cell death induction has been ongoing over the last years. A recent study identifies a new mechanism of action for the synergism of TRAIL and Bortezomib.
\end{abstract}

Evasion of apoptosis (programmed cell death) belongs to the hallmarks of cancers and contributes to tumor progression and treatment resistance [1]. There are two major apoptosis signaling pathways that culminate in the activation of caspases, i.e. the death receptor (extrinsic) pathway, which is triggered by the ligation of death receptors at the cell surface, and the mitochondrial (intrinsic) pathway, which involves the release of apoptogenic proteins from mitochondria into the cytosol to initiate caspase activation [2]. In principle, agents that trigger agonistic TRAIL receptors such as TRAIL receptor antibodies or recombinant soluble TRAIL present promising cancer therapeutics, since they can directly initiate the apoptotic machinery in cancer cells [3]. However, many human cancers have developed mechanisms to escape the induction of apoptosis upon treatment with TRAIL [4]. This underscores the need to identify and validate novel agents that could be used in combination protocols with TRAIL receptor targeting agents to potentiate the antitumor activity of TRAILbased regimens.

Inhibition of the proteasome presents one such strategy to enhance the sensitivity of cancer cells towards TRAIL. For example, Bortezomib (PS-341, VELCADE) is a dipeptidyl boronic acid compound that reversibly blocks the proteolytic activity of the proteasome and is a FDA-approved drugs for the treatment of multiple myeloma [5]. While Bortezomib has been shown to increase the sensitivity to TRAIL-induced apoptosis in several human cancers as single agent and in combination protocols $[6,7]$, the identification of the underlying molecular mechanisms that are responsible for this synergistic induction of apoptosis has been the subject of intensive investigations over the last years.

A recent study identifies a novel mechanism of action that underlies the synergistic cooperation of TRAIL and Bortezomib by demonstrating for the first time that Bortezomib enhances the stability of TRAILderived tBid, the cleaved form of Bid [8]. Bid is a pro-apoptotic BH3-only domain protein of the Bcl-2 family [9]. Upon stimulation of death receptors such as TRAIL receptors or CD95, activation of caspase-8 at the death-inducing signaling complex (DISC) results in the proteolytic processing of Bid into tBid [2]. tBid in turn translocates to mitochondria to promote activation of Bax and Bak, cytochrome c release into the cytosol and caspase activation, thus connecting the extrinsic to the intrinsic pathway of apoptosis [2]. The novelty of the current study resides in the demonstration that TRAIL and Bortezomib act together to cause the accumulation of tBid at the mitochondria [8]. To this end, tBid was found to accumulate at higher levels in cells that were treated with the combination of Bortezomib and TRAIL compared to cells that were exposed to TRAIL alone [8]. Since tBid has been reported to be prone to proteasomal degradation upon its ubiquitination [10], proteasome inhibition by Bortezomib prevents the degradation of tBid that is newly generated upon stimulation with TRAIL via TRAIL-induced caspase- 8 activation, leading to the accumulation of tBid. This conclusion is supported by data showing that cells, which were treated with TRAIL to trigger the cleavage of Bid to its truncated form $\mathrm{tBid}$, then washed to remove the remaining TRAIL and incubated in 
the presence of the broad-range caspase inhibitor zVAD. fmk to prevent any further processing of Bid by activated caspases, harboured markedly increased levels of tBid compared to cells, which were incubated in the absence of Bortezomib after the initial stimulation with TRAIL [8]. Since no tBid is produced any longer after removal of TRAIL and in the presence of the caspase inhibitor zVAD.fmk, neither by ongoing TRAIL stimulation (since TRAIL was removed by a washing step) nor by continued caspase activity (due to the addition of the wide-range caspase inhibitor zVAD.fmk), tBid levels under these experimental conditions are largely controlled by its degradation rate. Thus, the breakdown of tBid after TRAIL stimulation was substantially delayed in the presence of Bortezomib compared to cells that were incubated in the absence of Bortezomib after exposure to TRAIL. These findings support the conclusion that treatment with TRAIL results in cleavage of Bid into tBid, while the addition of Bortezomib markedly increases the stability of tBid that is produced by TRAIL-stimulated proteolytic cleavage. The functional relevance of $\mathrm{tBid}$ in the Bortezomib-conferred sensitization of neuroblastoma cells to TRAIL-induced apoptosis was demonstrated by RNA interference experiments showing that silencing of Bid also significantly reduced apoptosis in cells co-treated with TRAIL and Bortezomib [8]. Together, these results demonstrate that Bortezomib primes for TRAIL-mediated apoptosis at least in part by stabilizing $\mathrm{tBid}$.

Various mechanisms of action have been proposed to mediate the cooperative action of TRAIL and Bortezomib in the induction of apoptosis in cancer cells, involving modulation of both the extrinsic and the intrinsic pathway of apoptosis. As far as the intrinsic apoptosis signaling pathway is concerned, Bortezomib has been reported to stimulate upregulation of the $\mathrm{BH} 3$-only domain proteins
Bim and/or Bik $[11,12]$, to block the degradation of Bax [13] or to promote the release of Smac from the mitochondria into the cytosol [14]. Also, Bortezomib alone or in combination with TRAIL has been shown to downregulate or cleave anti-apoptotic Bcl-2 proteins such as $\mathrm{Bcl}-2, \mathrm{Bcl}-\mathrm{X}_{\mathrm{L}}$ or $\mathrm{Mcl}-1[15,16]$. It is interesting to note that Noxa turned out in the current study to determine only the kinetic of apoptosis induction, while it became dispensable for apoptosis upon prolonged exposure to Bortezomib and TRAIL [8]. In contrast, Noxa has been shown to be a critical mediator of apoptosis upon monotherapy with Bortezomib [17-19], pointing to differences in the role of Noxa between single agent and combination therapy with Bortezomib.

Bortezomib-mediated modulation of the extrinsic pathway of apoptosis has been attributed to upregulation of the agonistic TRAIL receptors TRAIL-R1 and/or TRAIL-R2 in several studies [16, 20-26], to promote the formation of the TRAIL DISC [27], to downregulate c-FLIP expression [27-29] or to block the degradation of caspase-8 [30]. Also, reduced expression of XIAP has been linked to Bortezomib-mediated sensitization to TRAIL-induced apoptosis [31-33] as well as inhibition of NF- $\kappa$ B by Bortezomib [24, 34].

In addition to providing new mechanistic insights into the synergistic interaction of Bortezomib and TRAIL the present study is the first demonstration that Bortezomib acts in concert with TRAIL in a childhood cancer, i.e. neuroblastoma. Previous studies on the combination of TRAIL and Bortezomib were performed in adult tumors. As single agent, Bortezomib has been reported to suppress neuroblastoma growth in preclinical studies [35-38], also in chemoresistant or metastatic disease [39-41]. By comparison, Bortezomib showed limited in vitro or in vivo activity as monotherapy when it was tested against

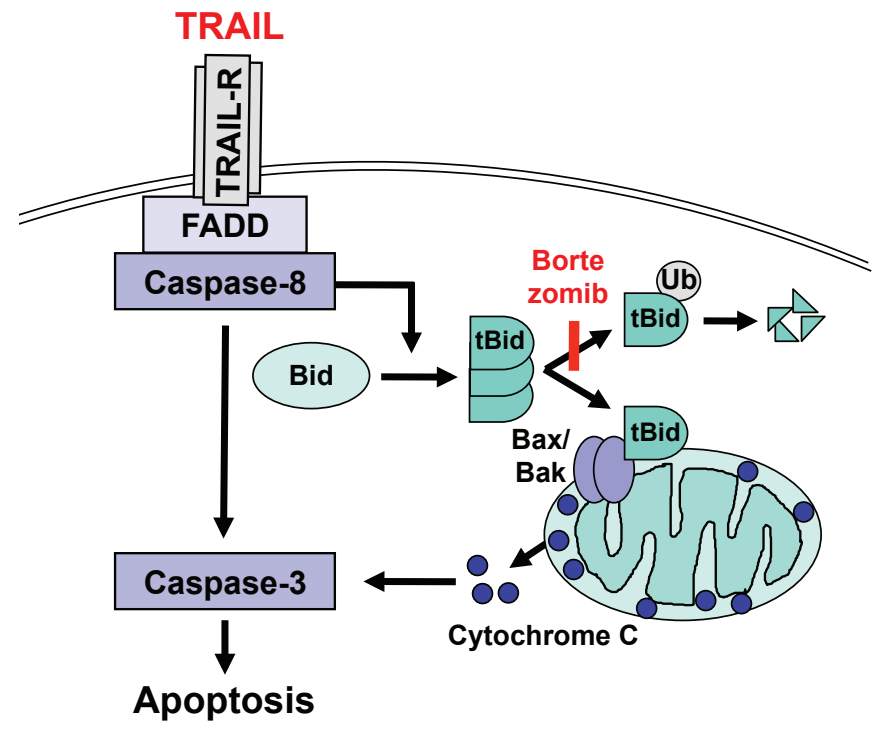

Figure 1: Scheme of the role of Bid for the synergistic interaction of TRAIL and Bortezomib. TRAIL induces cleavage of Bid into tBid, while Bortezomib increases the stabilization of tBid by inhibiting its proteasomal degradation, resulting in accumulation of tBid at mitochondrial membranes. This in turn promotes activation of Bax/Bak, release of cytochrome c from mitochondria into the cytosol, caspase- 3 activation and caspase-dependent apoptosis. 
the solid tumor cell line or xenograft panel of the pediatric preclinical testing program that includes models for neuroblastoma [42]. In phase I clinical trials in children with refractory solid tumors or leukemia Bortezomib proved to be well tolerated, although little single agent activity was reported $[43,44]$. Together with our findings showing that Bortezomib sensitizes neuroblastoma cells towards TRAIL, the currently available data indicate that Bortezomib represents an interesting experimental agent for the treatment of neuroblastoma especially in combination protocols, which warrants further investigation.

\section{REFERENCES}

1. Hanahan D, Weinberg RA. Hallmarks of cancer: the next generation. Cell. 2011; 144:646-674.

2. Fulda S, Debatin KM. Extrinsic versus intrinsic apoptosis pathways in anticancer chemotherapy. Oncogene. 2006; 25:4798-4811.

3. Ashkenazi A. Targeting the extrinsic apoptosis pathway in cancer. Cytokine Growth Factor Rev. 2008; 19:325-331.

4. Fulda S. Tumor resistance to apoptosis. Int J Cancer. 2009; 124:511-515.

5. Voorhees PM, Orlowski RZ. The proteasome and proteasome inhibitors in cancer therapy. Annu Rev Pharmacol Toxicol. 2006; 46:189-213.

6. Neznanov N, Komarov AP, Neznanova L, Stanhope-Baker P, Gudkov AV. Proteotoxic stress targeted therapy (PSTT): induction of protein misfolding enhances the antitumor effect of the proteasome inhibitor bortezomib. Oncotarget. 2011; 2:209-221.

7. Duensing S, Duensing A. Bortezomib: killing two birds with one stone in gastrointestinal stromal tumors. Oncotarget. 2011; 1:6-8.

8. Naumann I, Kappler R, von Schweinitz D, Debatin KM, Fulda S. Bortezomib primes neuroblastoma cells for TRAIL-induced apoptosis by linking the death receptor to the mitochondrial pathway. Clin Cancer Res. 2011.

9. Adams JM, Cory S. The Bcl-2 apoptotic switch in cancer development and therapy. Oncogene. 2007; 26:1324-1337.

10. Breitschopf K, Zeiher AM, Dimmeler S. Ubiquitinmediated degradation of the proapoptotic active form of bid. A functional consequence on apoptosis induction. J Biol Chem. 2000; 275:21648-21652.

11. Nikrad M, Johnson T, Puthalalath H, Coultas L, Adams J, Kraft AS. The proteasome inhibitor bortezomib sensitizes cells to killing by death receptor ligand TRAIL via BH3only proteins Bik and Bim. Mol Cancer Ther. 2005; 4:443449.

12. Zhu H, Guo W, Zhang L, Wu S, Teraishi F, Davis JJ, Dong F, Fang B. Proteasome inhibitors-mediated TRAIL resensitization and Bik accumulation. Cancer Biol Ther. 2005; 4:781-786.
13. Liu FT, Agrawal SG, Gribben JG, Ye H, Du MQ, Newland AC, Jia L. Bortezomib blocks Bax degradation in malignant B cells during treatment with TRAIL. Blood. 2008; 111:2797-2805.

14. Nagy K, Szekely-Szuts K, Izeradjene K, Douglas L, Tillman M, Barti-Juhasz H, Dominici M, Spano C, Luca Cervo G, Conte P, Houghton JA, Mihalik R, Kopper L, Petak I. Proteasome inhibitors sensitize colon carcinoma cells to TRAIL-induced apoptosis via enhanced release of Smac/DIABLO from the mitochondria. Pathol Oncol Res. 2006; 12:133-142.

15. Nencioni A, Wille L, Dal Bello G, Boy D, Cirmena G, Wesselborg S, Belka C, Brossart P, Patrone F, Ballestrero A. Cooperative cytotoxicity of proteasome inhibitors and tumor necrosis factor-related apoptosis-inducing ligand in chemoresistant Bcl-2-overexpressing cells. Clin Cancer Res. 2005; 11:4259-4265.

16. Conticello C, Adamo L, Giuffrida R, Vicari L, Zeuner A, Eramo A, Anastasi G, Memeo L, Giuffrida D, Iannolo G, Gulisano M, De Maria R. Proteasome inhibitors synergize with tumor necrosis factor-related apoptosis-induced ligand to induce anaplastic thyroid carcinoma cell death. J Clin Endocrinol Metab. 2007; 92:1938-1942.

17. Qin JZ, Ziffra J, Stennett L, Bodner B, Bonish BK, Chaturvedi V, Bennett F, Pollock PM, Trent JM, Hendrix MJ, Rizzo P, Miele L, Nickoloff BJ. Proteasome inhibitors trigger NOXA-mediated apoptosis in melanoma and myeloma cells. Cancer Res. 2005; 65:6282-6293.

18. Perez-Galan P, Roue G, Villamor N, Montserrat E, Campo E, Colomer D. The proteasome inhibitor bortezomib induces apoptosis in mantle-cell lymphoma through generation of ROS and Noxa activation independent of p53 status. Blood. 2006; 107:257-264.

19. Fribley AM, Evenchik B, Zeng Q, Park BK, Guan JY, Zhang H, Hale TJ, Soengas MS, Kaufman RJ, Wang CY. Proteasome inhibitor PS-341 induces apoptosis in cisplatinresistant squamous cell carcinoma cells by induction of Noxa. J Biol Chem. 2006; 281:31440-31447.

20. Yoshida T, Shiraishi T, Nakata S, Horinaka M, Wakada M, Mizutani Y, Miki T, Sakai T. Proteasome inhibitor MG132 induces death receptor 5 through CCAAT/enhancerbinding protein homologous protein. Cancer Res. 2005; 65:5662-5667.

21. He Q, Huang Y, Sheikh MS. Proteasome inhibitor MG132 upregulates death receptor 5 and cooperates with Apo2L/ TRAIL to induce apoptosis in Bax-proficient and -deficient cells. Oncogene. 2004; 23:2554-2558.

22. Johnson TR, Stone K, Nikrad M, Yeh T, Zong W-X, Thompson CB, Nesterov A, Kraft AS. The proteasome inhibitor PS-341 overcomes TRAIL resistance in Bax and caspase 9-negative or Bcl-xL overexpressing cells. Oncogene. 2003; 22:4953-4963.

23. Liu X, Yue P, Chen S, Hu L, Lonial S, Khuri FR, Sun S-Y. The proteasome inhibitor PS-341 (bortezomib) upregulates DR5 expression leading to induction of apoptosis 
and enhancement of TRAIL-induced apoptosis despite up-regulation of c-FLIP and survivin expression in human NSCLC cells. Cancer Res. 2007; 67:4981-4988.

24. Voortman J, Resende TP, Abou El Hassan MA, Giaccone G, Kruyt FA. TRAIL therapy in non-small cell lung cancer cells: sensitization to death receptor-mediated apoptosis by proteasome inhibitor bortezomib. Mol Cancer Ther. 2007; 6:2103-2112.

25. Hetschko H, Voss V, Seifert V, Prehn JH, Kogel D. Upregulation of DR5 by proteasome inhibitors potently sensitizes glioma cells to TRAIL-induced apoptosis. FEBS J. 2008; 275:1925-1936.

26. Kandasamy K, Kraft AS. Proteasome inhibitor PS-341 (VELCADE) induces stabilization of the TRAIL receptor DR5 mRNA through the 3'-untranslated region. Mol Cancer Ther. 2008; 7:1091-1100.

27. Koschny R, Holland H, Sykora J, Haas TL, Sprick MR, Ganten TM, Krupp W, Bauer M, Ahnert P, Meixensberger J, Walczak H. Bortezomib sensitizes primary human astrocytoma cells of WHO grades I to IV for tumor necrosis factor-related apoptosis-inducing ligand-induced apoptosis. Clin Cancer Res. 2007; 13:3403-3412.

28. Sayers TJ, Brooks AD, Koh CY, Ma W, Seki N, Raziuddin A, Blazar BR, Zhang X, Elliott PJ, Murphy WJ. The proteasome inhibitor PS-341 sensitizes neoplastic cells to TRAIL-mediated apoptosis by reducing levels of c-FLIP. Blood. 2003; 102:303-310.

29. Zhao X, Qiu W, Kung J, Peng X, Yegappan M, YenLieberman B, Hsi ED. Bortezomib induces caspasedependent apoptosis in Hodgkin lymphoma cell lines and is associated with reduced c-FLIP expression: a gene expression profiling study with implications for potential combination therapies. Leuk Res. 2008; 32:275-285.

30. Thorpe JA, Christian PA, Schwarze SR. Proteasome inhibition blocks caspase- 8 degradation and sensitizes prostate cancer cells to death receptor-mediated apoptosis. Prostate. 2008; 68:200-209.

31. Leverkus M, Sprick MR, Wachter T, Mengling T, Baumann B, Serfling E, Brocker E-B, Goebeler M, Neumann M, Walczak H. Proteasome inhibition results in TRAIL sensitization of primary keratinocytes by removing the resistance-mediating block of effector caspase maturation. Mol Cell Biol. 2003; 23:777-790.

32. Inoue T, Shiraki K, Fuke H, Yamanaka Y, Miyashita K, Yamaguchi Y, Yamamoto N, Ito K, Sugimoto K, Nakano T. Proteasome inhibition sensitizes hepatocellular carcinoma cells to TRAIL by suppressing caspase inhibitors and AKT pathway. Anticancer Drugs. 2006; 17:261-268.

33. Kashkar H, Deggerich A, Seeger JM, Yazdanpanah B, Wiegmann K, Haubert D, Pongratz C, Kronke M. NF-kappaB-independent down-regulation of XIAP by bortezomib sensitizes HL B cells against cytotoxic drugs. Blood. 2007; 109:3982-3988.

34. Khanbolooki S, Nawrocki ST, Arumugam T, Andtbacka
R, Pino MS, Kurzrock R, Logsdon CD, Abbruzzese JL, McConkey DJ. Nuclear factor-kappaB maintains TRAIL resistance in human pancreatic cancer cells. Mol Cancer Ther. 2006; 5:2251-2260.

35. Brignole C, Marimpietri D, Pastorino F, Nico B, Di Paolo D, Cioni M, Piccardi F, Cilli M, Pezzolo A, Corrias MV, Pistoia V, Ribatti D, Pagnan G, Ponzoni M. Effect of bortezomib on human neuroblastoma cell growth, apoptosis, and angiogenesis. J Natl Cancer Inst. 2006; 98:1142-1157.

36. Khan T, Stauffer JK, Williams R, Hixon JA, Salcedo R, Lincoln E, Back TC, Powell D, Lockett S, Arnold AC, Sayers TJ, Wigginton JM. Proteasome inhibition to maximize the apoptotic potential of cytokine therapy for murine neuroblastoma tumors. J Immunol. 2006; 176:63026312.

37. Hamner JB, Dickson PV, Sims TL, Zhou J, Spence Y, Ng CY, Davidoff AM. Bortezomib inhibits angiogenesis and reduces tumor burden in a murine model of neuroblastoma. Surgery. 2007; 142:185-191.

38. Combaret V, Boyault S, Iacono I, Brejon S, Rousseau R, Puisieux A. Effect of bortezomib on human neuroblastoma: analysis of molecular mechanisms involved in cytotoxicity. Mol Cancer. 2008; 7:50.

39. Armstrong MB, Schumacher KR, Mody R, Yanik GA, Opipari AW, Jr., Castle VP. Bortezomib as a therapeutic candidate for neuroblastoma. J Exp Ther Oncol. 2008; 7:135-145.

40. Michaelis M, Fichtner I, Behrens D, Haider W, Rothweiler F, Mack A, Cinatl J, Doerr HW, Cinatl J, Jr. Anti-cancer effects of bortezomib against chemoresistant neuroblastoma cell lines in vitro and in vivo. Int J Oncol. 2006; 28:439446.

41. Valentiner U, Haane C, Nehmann N, Schumacher U. Effects of bortezomib on human neuroblastoma cells in vitro and in a metastatic xenograft model. Anticancer Res. 2009; 29:1219-1225.

42. Houghton PJ, Morton CL, Kolb EA, Gorlick R, Lock R, Carol H, Reynolds CP, Maris JM, Keir ST, Billups CA, Smith MA. Initial testing (stage 1) of the mTOR inhibitor rapamycin by the pediatric preclinical testing program. Pediatr Blood Cancer. 2008; 50:799-805.

43. Blaney SM, Bernstein M, Neville K, Ginsberg J, Kitchen B, Horton T, Berg SL, Krailo M, Adamson PC. Phase I study of the proteasome inhibitor bortezomib in pediatric patients with refractory solid tumors: a Children's Oncology Group study (ADVL0015).[erratum appears in J Clin Oncol. 2005 Jan 1;23(1):248]. J Clin Oncol. 2004; 22:4804-4809.

44. Horton TM, Pati D, Plon SE, Thompson PA, Bomgaars LR, Adamson PC, Ingle AM, Wright J, Brockman AH, Paton M, Blaney SM. A phase 1 study of the proteasome inhibitor bortezomib in pediatric patients with refractory leukemia: a Children's Oncology Group study. Clin Cancer Res. 2007; 13:1516-1522. 